\title{
Effects of Seed Pretreatment on Germination, Growth and Yield of Momordica charantia L.
}

\author{
Samba Balde ${ }^{1,2 *}$, Nicolas Cyrille Ayessou ${ }^{1,2}$, Antoine Sambou ${ }^{3}$, Khadim Niane ${ }^{1,2}$, \\ Papa Guedel Faye ${ }^{1,2}$, Mady Cisse ${ }^{1,2}$, Codou Mar Diop ${ }^{1,2}$ \\ ${ }^{1}$ Polytechnic Higher School, Cheikh Anta Diop University, Dakar, Sénégal \\ ${ }^{2}$ Center for Studies on Food Safety and Functional Molecules (CESAM), Cheikh Anta Diop University, Dakar, Sénégal \\ ${ }^{3}$ Department of Agroforestry Assane Seck University of Ziguinchor, Sénégal \\ Email: *balsamba2013@yahoo.fr
}

How to cite this paper: Balde, S., Ayessou, N.C., Sambou, A., Niane, K., Faye, P.G., Cisse, M. and Diop, C.M. (2021) Effects of Seed Pretreatment on Germination, Growth and Yield of Momordica charantia L. Agricultural Sciences, 12, 39-57.

https://doi.org/10.4236/as.2021.121004

Received: December 15, 2020

Accepted: January 26, 2021

Published: January 29, 2021

Copyright $\odot 2021$ by author(s) and Scientific Research Publishing Inc. This work is licensed under the Creative Commons Attribution International License (CC BY 4.0).

http://creativecommons.org/licenses/by/4.0/

\begin{abstract}
Momordica charantia is a plant species widely used in food and traditional medicine. However, the germination techniques and the performances of $M$. charantia are poorly understood by the populations. This study aims to better understand the germination, growth and development characteristics, and yield of $M$. charantia. Three pretreatments of the seeds are used for the shortening of the pre-germination period: soaking the seeds in tap water for 24 hours (batch 2), in hot water at $80^{\circ} \mathrm{C}$ (batch 3), for 24 hours and in the boiling water at $100^{\circ} \mathrm{C}$ for 24 hours (batch 4). A control without soaking (batch 1) was also carried out. The seeds were sown in plastic boxes in the laboratory with sterile sand and directly in the nursery in polyethylene sleeves. The influence of the light factor (light and dark) and watering frequency (every day and every two days) on the growth and yield parameters was evaluated respectively in the laboratory and in the nursery. Germination, growth and yield parameters were determined. The results show that the light and frequency of watering factors have no influence $(\mathrm{p}>0.05)$ on the rate and duration of seed germination unlike pretreatments. Thus, Batch 1 and 2 exhibit significantly higher germination rates $(70 \% \pm 16 \%)$ than Lots 3 and 4 $(21 \% \pm 15 \%)$ in the laboratory and in the nursery. On the other hand in terms of germination time, batch 3 and 4 displayed shorter durations (14 days) than those batch 1 and 2 (23 days). Growth parameters and yield (fruit and seeds) are strongly influenced by watering frequency, unlike pretreatments which only affect yield. Growth and yield parameters are significantly higher with daily watering than daily watering. Ultimately, this study showed that pretreatments have an influence on the duration and rate of germination as well as the frequency of watering on the performance of $M$. charantia.
\end{abstract}




\section{Keywords}

Momordica charantia, Germination, Performance, Yield

\section{Introduction}

The untapped diversity of neglected and underutilized species are important sources of nutrients, especially proteins, vitamins and micronutrients that are scarce in major staple crops. Today, the recommendations of institutions and organizations including the world Food and Agriculture Organization (FAO) aimed at increasing the productivity and quality of the agricultural sector in developing countries are focused primarily on under-utilized crops [1]. Among these neglected species are the cucurbits, some of which are important for food and especially medicinal crops, are attracting the attention of populations [2]. These cucurbits like most neglected and underutilized plants in Africa have great agronomic and sanitary potential. Moreover, they are well adapted to extremely varied agro-ecosystems and cropping systems [3]. Therefore, increasing the production and use of these cucurbits can help ensure health and food security and diversify the income of smallholder farmers [1]. Thus, Momordica charantia, also known as bitter gourd, bitter melon and Karela, belongs to the Cucurbitaceae family, generally consumed as a food (bitter flavor) in India and traditionally used to treat diabetes and other chronic diseases [4] [5]. It is cultivated for its edible fruits and consumed as a vegetable because of its medicinal properties. In addition, the leaves and stems are used to cure diseases due to its hypoglycemic effect [6]. In addition, studies have shown that it contains bioactive compounds such as charantin, vicin, glycoalkaloids and polypeptids [7]. It is also used to treat inflammation, colds, hypertension, sore throat, menstrual pain, tuberculosis, anemia, kidney stones, malaria, anorexia and vomiting [8]. In general, the cultivation of the plant makes use of fertile land and synthetic inputs such as fertilizers used to increase germination and yield [3]. Indeed, in Senegal, the plant is little or not cultivated by the populations. Usually it is used in the wild specifically for traditional medicine and the fruits are consumed very little by the indigenous populations [9]. However, most cultivators of $M$. charantia face a problem of germination by the seed dormancy and whim. It is therefore necessary to use new germination and reproduction technologies to increase the production of the plant. Moreover, the importance of pretreatment by several methods on seed germination has been studied by various researchers since the 19th century [10] to improve the germination rate, the vigor of the seedlings and the growth at the later stages of plant development [11]. In this context, the objective of this study is to assess on the one hand the germination rate of seeds in the laboratory and in the nursery, and on the other hand the growth rate of seedlings and seed yield of $M$. charantia L. 


\section{Materials and Methods}

\subsection{Study Area}

The experiment was carried out at the National Forest Seeds Program laboratory and at the Mbao forest service site located in the Pikine districk in Dakar (Figure 1). Two experiments were carried out on the site: the first was carried out between May and June 2018 in the laboratory and the second between June and November 2018 in the nursery.

\subsection{Vegetal Material}

The vegetal material used was the seeds of $M$. charantia collected between November and January 2017 in the Niayes area (Dakar). Fruits were harvested at maturity to ensure good seed quality. After the fruit extraction phase, the seeds obtained were washed and dried to the open air in the sun (Figure 2). Then the dried seeds were sorted manually to eliminate the bad quality ones. Finally, the sorted healthy seeds were used for the germination test according to the pretreatments.

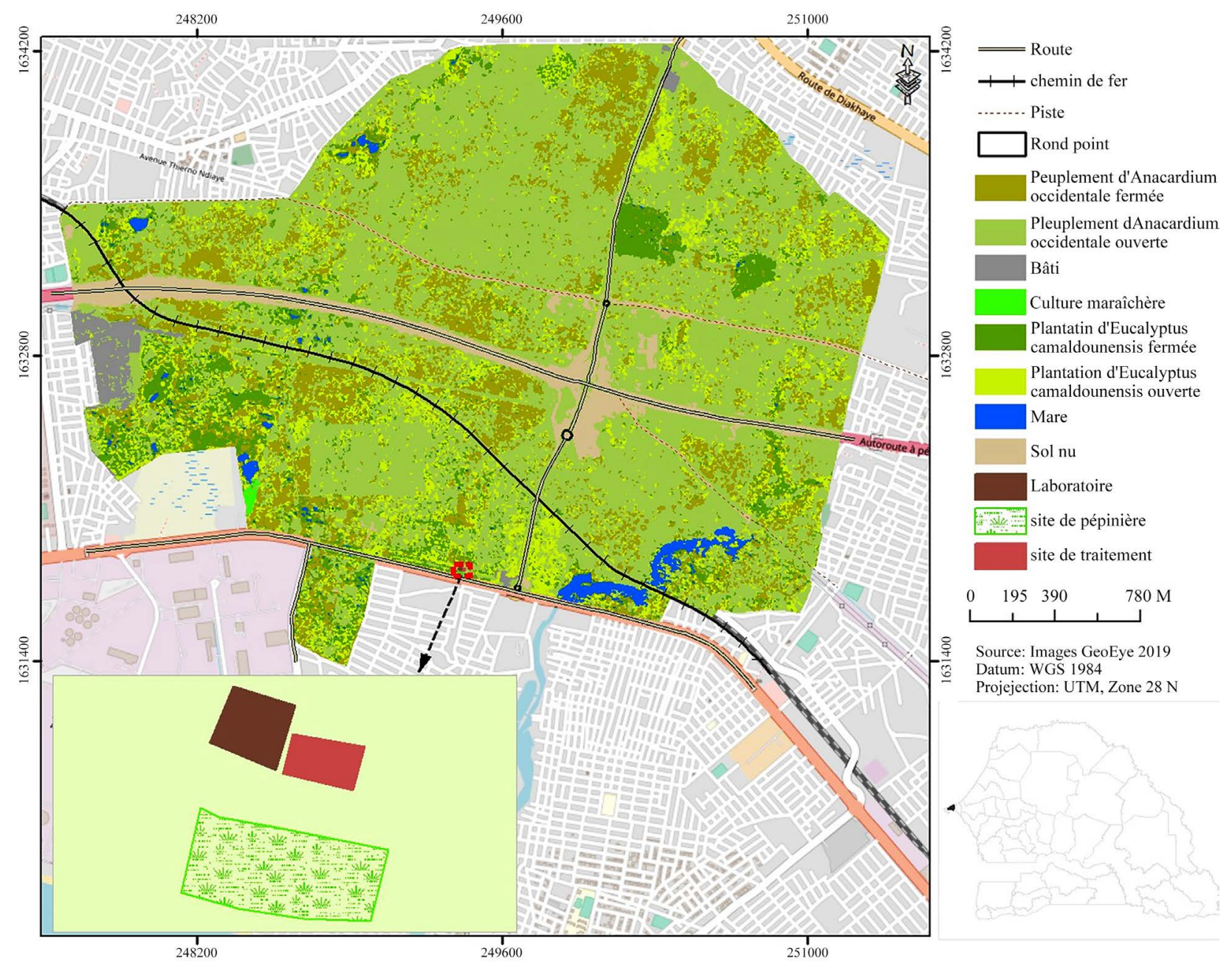

Figure 1. Location of the experimental sites. 


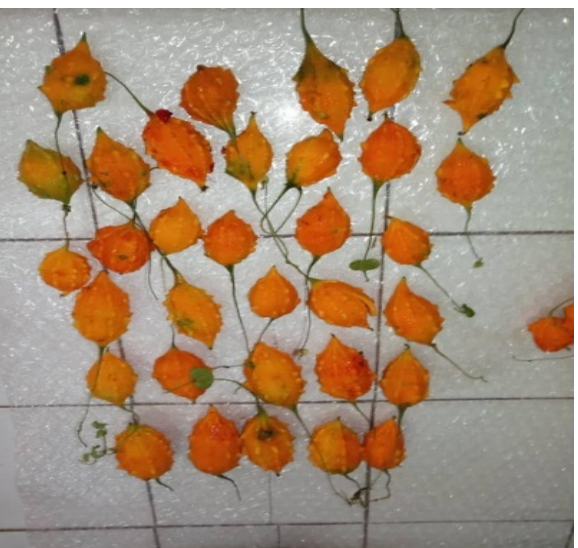

(a)

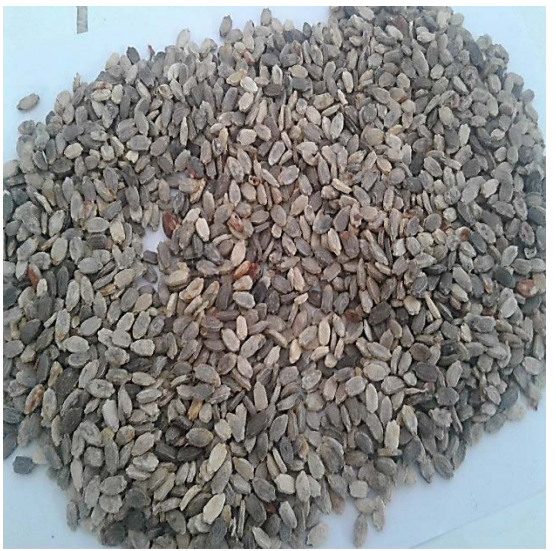

(b)

Figure 2. Seed treatment process: (a) Fruits, (b) Seeds washed, dried and sorted.

\subsection{Pretreatments}

In the laboratory, four pretreatments were tested in germination boxes. Each pretreatment had two replicates containing 50 seeds. All the germination boxes were distributed according to a random arrangement (Figure 3(a) \& Figure 3(b)). Four $M$. charantia seed lots were subjected to the pretreatments which are: (Lot1) control, that is to say untreated seeds; (Lot2) seeds soaked in tap water for 24 hours followed by rinsing the seeds three times in distilled water; (Lot3) seeds soaked in hot water at $90^{\circ} \mathrm{C}$ for 24 hours followed by rinsing the seeds three times in tap water; (Lot4) soaking in boiling water at $100^{\circ} \mathrm{C}$ for 24 hours followed by rinsing the seeds three times in distilled water (photo). Then the four lots of 100 seeds each are divided into lots of 50 seeds placed in different places. Of these 08 lots, four are exposed to light and the other four are exposed to darkness. For germination, sand sterilized in an oven at $150^{\circ} \mathrm{C}$ for 24 hours to kill all microorganisms was used.

\subsection{Preparation of Substrates and Mixtures}

In this part, the substrate used was a mixture of erosive soil (sand) and manure. The mixture had been made up of the following different proportion/ratio: $2 / 3$ sand $+1 / 3$ manure. Black polyethylene bags of $21 \mathrm{~cm} \times 7.5 \mathrm{~cm}$ were used for potting purposes. Before sowing in the bags, the seeds were subjected to pretreatments in the laboratory.

\subsection{Experimental Design}

The sowing was done with two seeds per pot, to a depth of approximately 1.5 $\mathrm{cm}$. The experiment was carried out in the PRONASEF (national forest seeds program) botanical garden at the Mbao water and forest site. All pots were placed in the nursery and watered regularly according to a completely random block arrangement with two treatments. The treatment (T1) is watered every day morning and afternoon, and the treatment (T2) watered every two days morning 


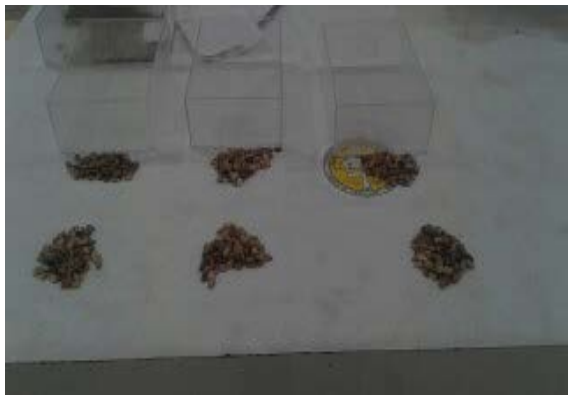

(a)

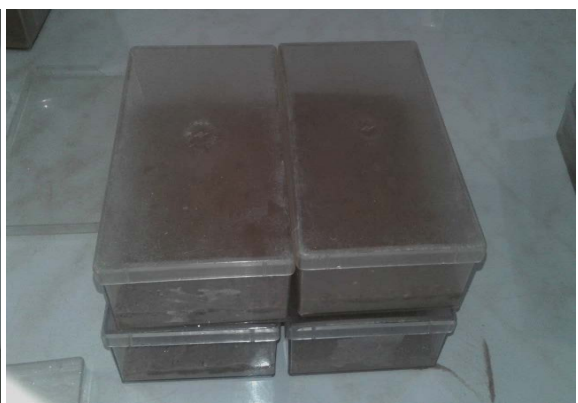

(b)

Figure 3. Seed germination process: Lots of seeds (a), germination boxes (b).

and afternonn. Each experimental unit consists of four (4) rows of 100 pots for a total of 400 pots with each pot a seed. Watering was carried out according to the frequency of irrigation at the rate of half liter per pot. In the nursery, the emergence of seedlings was monitored every day from the third day of sowing between the beginning of July and the end of August 2018. The emergence was taken into account as soon as the seedling was visible. A systematic count of the seedlings that have emerged until the end of germination was carried out every day until the 30th day of germination. A random sample of four pots per repetition and per batch, is taken every week for two months to measure the height and the number of leaves. Several yield parameters such as the number of fruit per plant, the average number of seeds per fruit and the yield of seeds were evaluated.

\subsection{Data Collection}

To determine the germination rate, we considered the number of seeds emerged and the emergence of seedlings. Thus a seed was considered to have germinated when the cotyledons separate to allow the radicle to emerge. Therefore the total germination rate, the germination rates by pretreatment were calculated. Growth parameters such as height and number of leaves were evaluated. These parameters were determined at eight-day intervals from 10 to 30 days after sowing (DAS). After three (3) months, the experiment ended with the harvest of fruits in order to determine the number of fruit per plant, the number of seeds per fruit and the total yield per plot of $150 \mathrm{~m}^{2}$.

\subsection{Data Treatment and Analysis}

The germination criteria and parameters are those defined by Soumana et al. [12] according to which the latency time (germination time) is the time elapsed between sowing and the first germination. The duration of germination or staggering is the time between the first and the last germination. A seed is considered germinated when the radicle pierces the seed coats. The counting of germinated seeds is carried out daily for 30 days. The parameters studied are: The germination rate (TG) which represents the number of seeds germinated compared to the number of total seeds germinated. This parameter is a better way to 
determine the germination capacity of seeds. It is expressed as a percentage and calculated from the type of pretreatment and the substrate according to the following formula [13]:

$$
\text { Germination rate }(\%)=\frac{\text { Number of seeds germinated }}{\text { Total number of seeds sown }} \times 100
$$

The germination kinetics (the number of seeds germinated) was noted every 24 hours for 30 days. Average Germination Time (GMT) which was the number of seeds germinated relative to the number of days (time) is determined. In this study, data such as germination rate, height, number of leaves, number of fruit per plant, number of seed per fruit and total yield were collected and placed in tables of database using Excel 2013. ANOVAs were used to compare means of variables by Fisher's test (multiple comparison tests with Tukey's test) at the 5\% level.

\section{Results}

\subsection{Germination of Momordica charantia Seeds}

\subsubsection{Germination Kinetics}

\section{* In the laboratory}

The evolution of seed germination per day for all the pretreatments on different degrees of light parameters (light and dark) showed different daily germination rates (Figure 4 and Figure 5). In light, germination started on the third day for the control (Lot1) and for the seeds soaked in tap water for 24 hours (Lot2) and on the fifth day for the seeds soaked in hot water at $80^{\circ} \mathrm{C}$. (Lot3) and in boiling water at $100^{\circ} \mathrm{C}$ (Lot 4). The most important germination (peak) was noted on the 9th day for Lot 2 with $14 \%$, on the 10th day for Lot $4(3 \%)$ and on the 11th day for Lots 1 and 3 respectively (10.5\% and 7\%) (Figure 4). While in darkness, Germination began from the fourth day for Lot2, the sixth day for Lots 3 and 4, the seventh day for batch 1 . The germination rate in Lot 1 gradually increased and reached the maximum (11\%) at the 13th day after sowing. For Lot 2, germination reached the maximum (13\%) on the 10th day. The same tangency was noted for Lots 4,3 and 1, the peaks of which were recorded on the ninth, 11 th and 12 th day respectively.

\section{* In the nursery}

Graphical analysis of the evolution of germination of $M$. charantia seeds in the nursery with the frequency of watering showed a variation in the dynamics of daily germination (Figure 6 and Figure 7). The early germination varied between four and seven days after sowing (DAS) depending on the pretreatments and frequency of watering. The frequency of watering every day influenced the lots 1 and 2 by improving the germination and reducing the latency time. However, the control gives more germination from the 20th DAS. While for Lots s 3 and 4, a longer time and lower germination of the seeds were observed. The time from sowing to the first emergence of seedlings was four days and the emergence interval is 29 days. Watering every two days favored more total germination for 
Lots 1 and 2 with a shorter latency time of the latter. Lot 2 recorded the better germination (Figure 6).

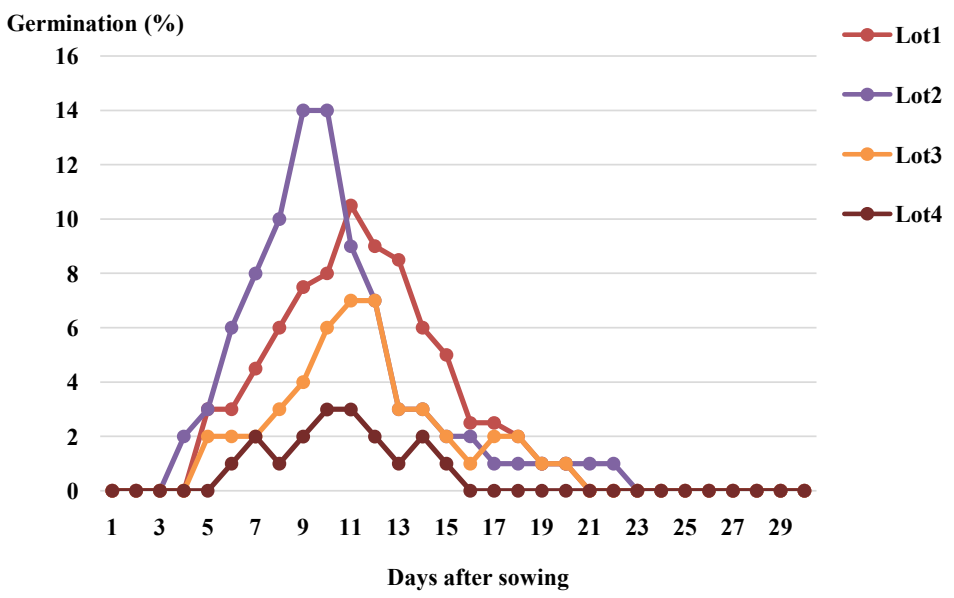

Figure 4. Germination kinetics of $M$. charantia seeds in the light.

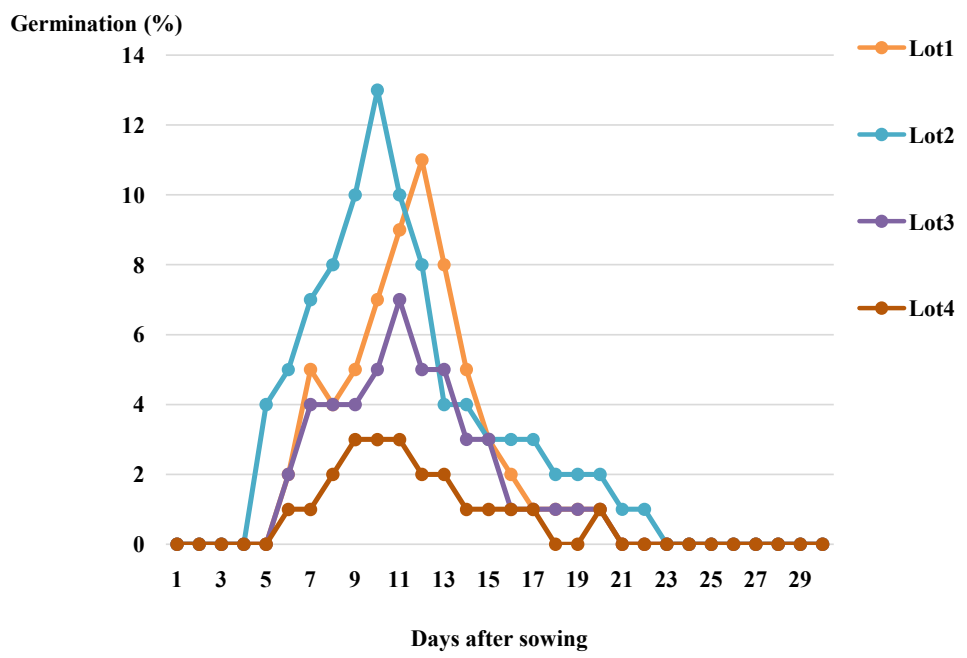

Figure 5. Germination kinetics of $M$. charantia seeds in the darkness.

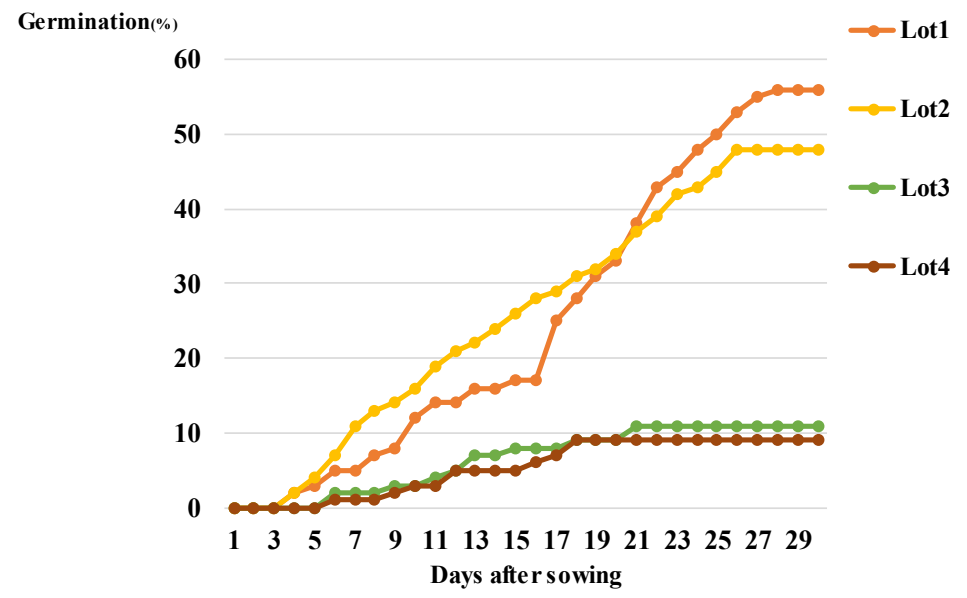

Figure 6. Germination kinetics of $M$. charantia seeds in nursery watering every day. 


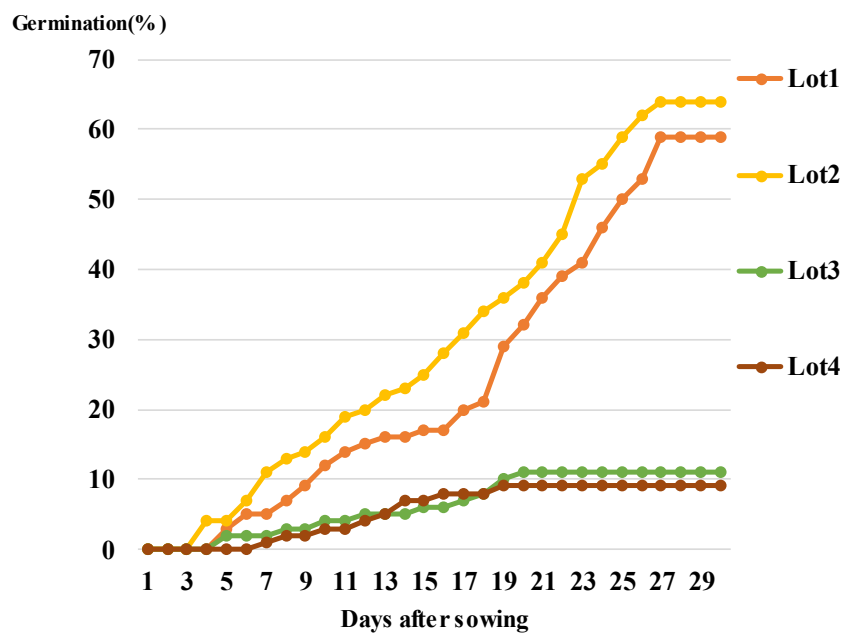

Figure 7. Germination kinetics in nursery watering every two days.

\subsubsection{Duration and Germination Rate}

The degree of light and frequency of watering factors did not influence ( $\mathrm{p}>$ 0.05 ) the duration and rate of seed germination (Figure 8(a) \& Figure 8(b) and Figure 9(a) \& Figure 9(b)). The results obtained showed that the rate and duration of germination varied considerably depending on the different pretreatments. The analysis of variance showed that there was a significant difference ( $p$ $\leq 0.05$ ) between the pretreatments (Table 1). Lots 1 and 2 allowed the highest germination rates in the laboratory and in the nursery respectively $(79 \%$ and $86.75 \% ; 61 \%$ and 50.75\%) with longer germination times (22 and 18.12; 26 and 24 days). On the other hand, Lots 3 and 4 recorded lower germination rates, respectively ( $42.37 \%$ and $11.75 \% ; 22 \%$ and $9.5 \%$ ) with shorter germination times (15.5 and 15.75; and 11.5 and 14.5 days).

\subsection{Assessment of Plant Growth Parameters}

The change in the height overtime depended overtime on the pretreatments (Figure 10). The increasing trend of evolution of all the curves obtained was almost the same. But the height growth rate was faster in Lots 1 and 2 than in Lots 3 and 4 .

The evolution of the number of leaves was higher in the plants from Lots 1 and 2 compared to the other two pretreatments (Figure 11). The slight drop observed at the level of the curves of the plants pretreated with hot water (Lot3) and those treated with boiling water (Lot4), would be due to an elongation of the main stem, which occurred between the 39th and 60th days after sowing (DAS).

The results showed that the frequency of watering had a significant influence on the growth parameters (Figure 12(a) \& Figure 12(b)). In fact, watering every day promoted more growth in height $(4.5 \mathrm{~m})$ and number of leaves $(98)$ than watering every two days ( $3.08 \mathrm{~m}$ and 86 leaves). The pretreatments did not significantly influence the growth parameters (Table 2). However, the average height of a $M$. charantia plant was $3.75 \mathrm{~m}$ with an average leaf count of 92.03 . 

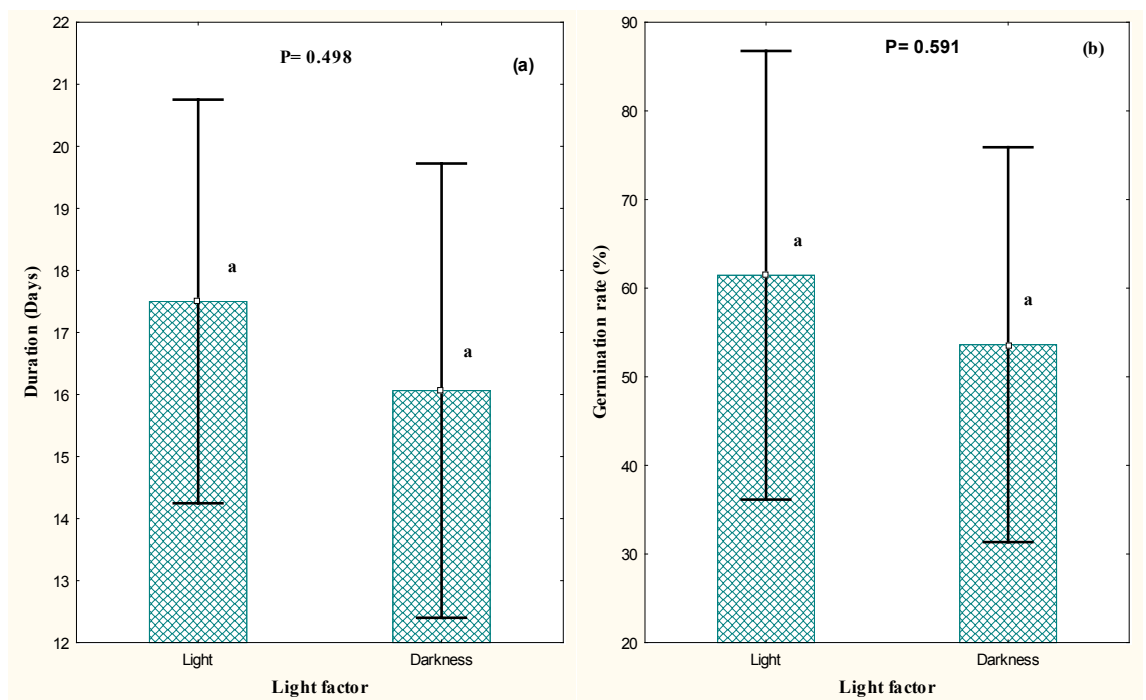

Figure 8. Effect of light degree on the germination duration (a) and rate (b) of $M$. charantia seeds.
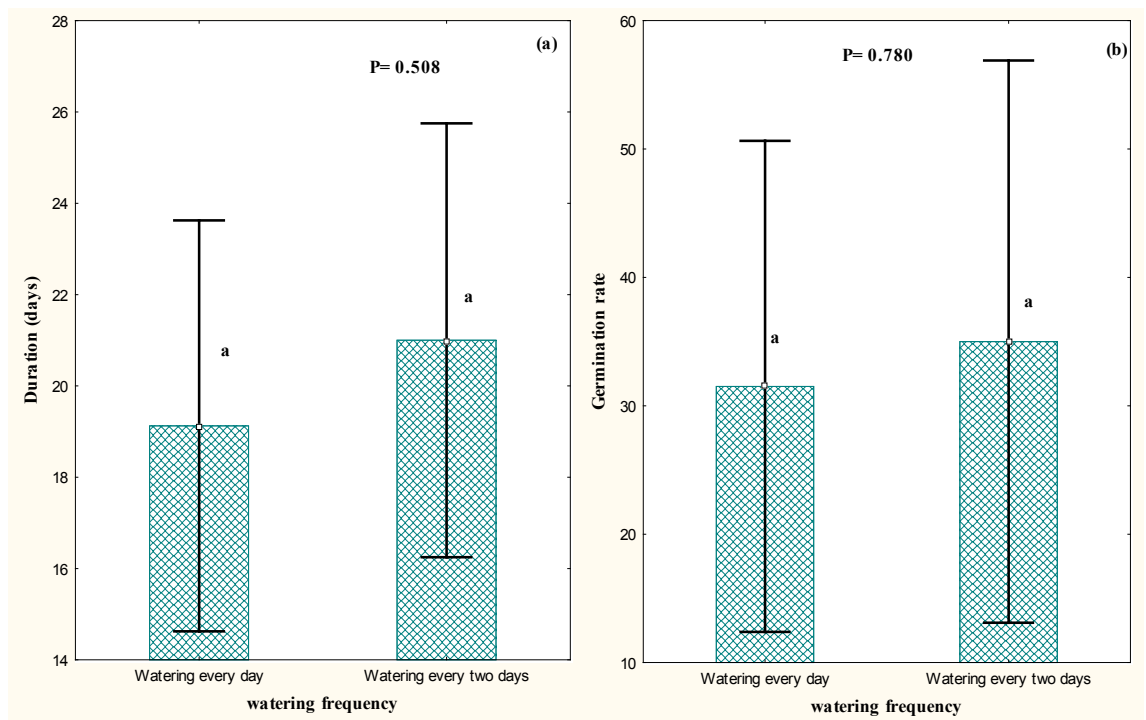

Figure 9. Effect of watering frequency on the germination duration (a) and rate (b) of $M$. charantia.

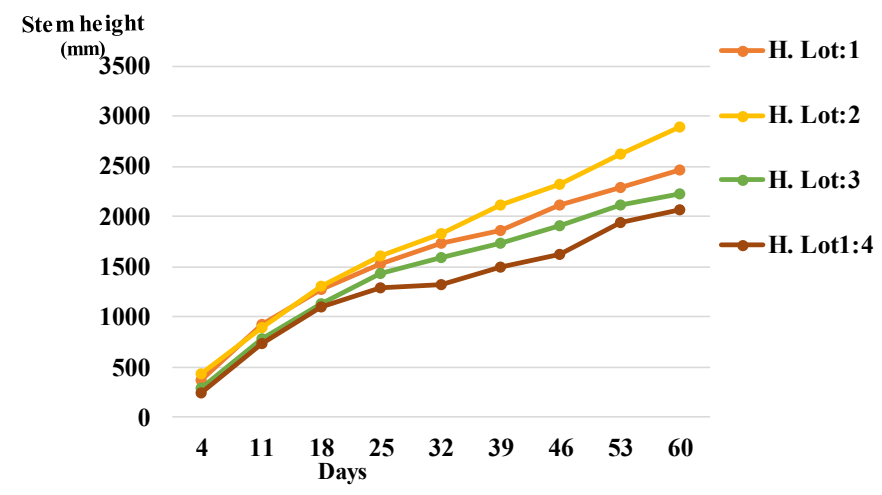

Figure 10. Evolution of the height according to the treatment. 
Number of sheets

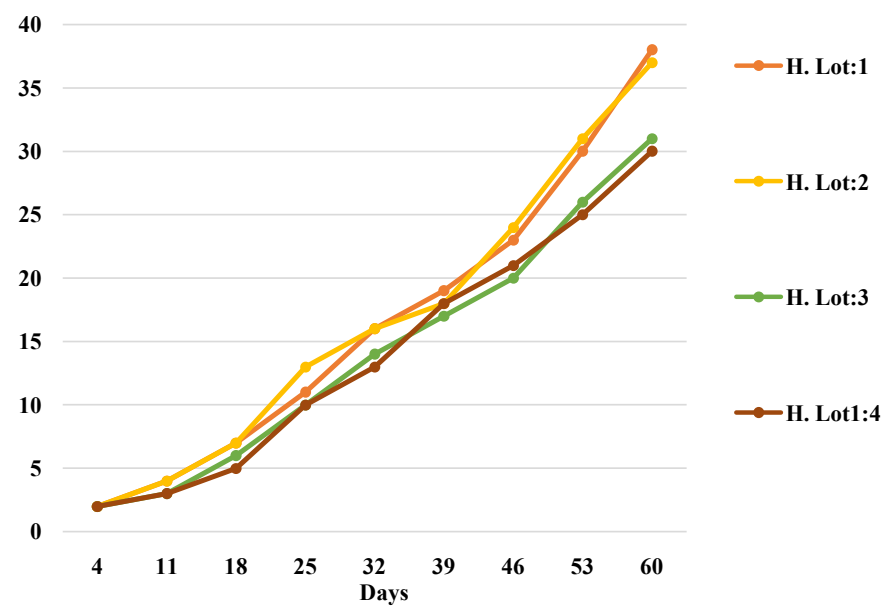

Figure 11. Evolution of the growth of the aerial parts according to the treatment.
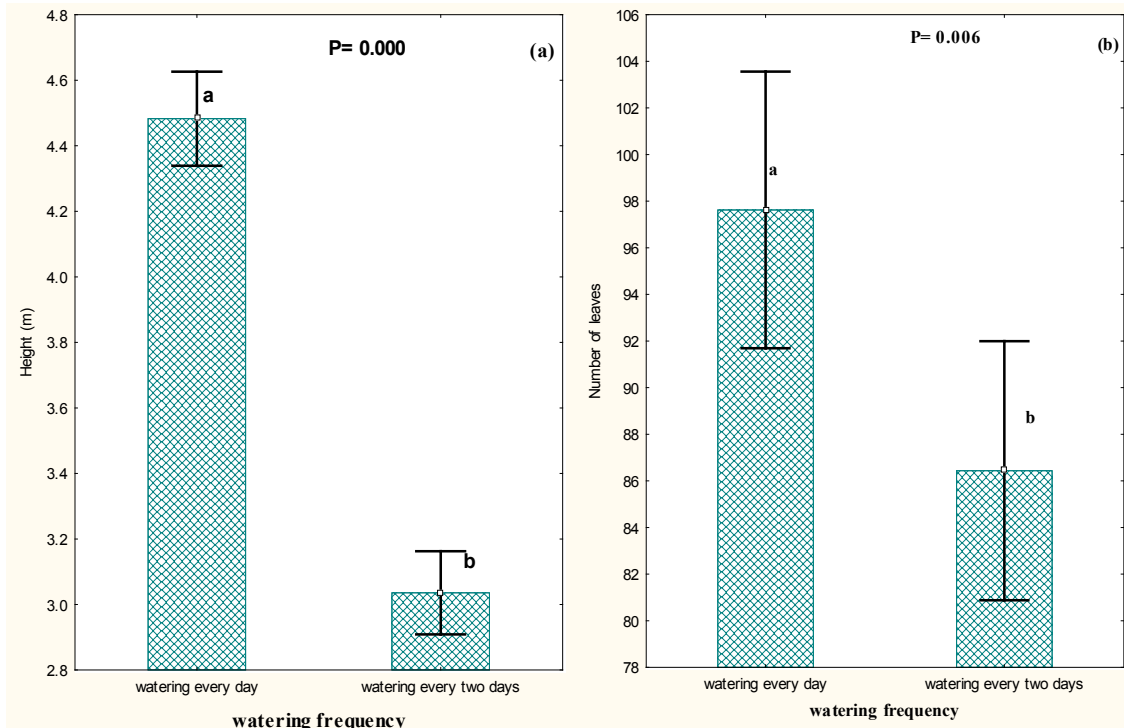

Figure 12. Evaluation of growth parameters: (a) height and (b) number of leaves.

Table 1. Comparison of germination duration and rates of $M$. charantia seeds in the laboratory and the nursery.

\begin{tabular}{|c|c|c|c|c|}
\hline \multirow{2}{*}{$\begin{array}{c}\text { Settings } \\
\text { Treatments }\end{array}$} & \multicolumn{2}{|c|}{ Duration (days) } & \multicolumn{2}{|c|}{ Germination rates (\%) } \\
\hline & Laboratory & Nursery & laboratory & nursery \\
\hline Lot: 1 & $18.12 \pm 0.85^{\mathrm{a}}$ & $26 \pm 1.15^{\mathrm{a}}$ & $79 \pm 8.97^{\mathrm{ab}}$ & $50.75 \pm 4.83^{\mathrm{a}}$ \\
\hline Lot: 2 & $22 \pm 0.81^{b}$ & $24 \pm 3.16^{\mathrm{a}}$ & $86.75 \pm 4.36^{\mathrm{b}}$ & $61 \pm 3.24^{\mathrm{b}}$ \\
\hline Lot: 3 & $15.5 \pm 1.29^{\mathrm{a}}$ & $15.75 \pm 0.95^{\mathrm{b}}$ & $42.37 \pm 6.01^{\mathrm{ac}}$ & $11.75 \pm 1.29^{c}$ \\
\hline Lot: 4 & $11.5 \pm 1.29^{\mathrm{ab}}$ & $14.5 \pm 1.29^{\mathrm{b}}$ & $22 \pm 0.68^{c}$ & $9.5 \pm 0.70^{c}$ \\
\hline P-value & 0.00 & 0.00 & 0.00 & 0.00 \\
\hline
\end{tabular}


Table 2. Summary of pretreatments on growth parameters.

\begin{tabular}{ccc}
\hline Treatments & height $(\mathrm{m})$ & number of leaves \\
\hline Lot: 1 & $3.74 \pm 0.95^{\mathrm{a}}$ & $87.2 \pm 13.61^{\mathrm{a}}$ \\
Lot: 2 & $3.74 \pm 0.79^{\mathrm{a}}$ & $88.5 \pm 10.84^{\mathrm{a}}$ \\
Lot: 3 & $3.61 \pm 0.65^{\mathrm{a}}$ & $91.25 \pm 9.96^{\mathrm{a}}$ \\
Lot: 4 & $3.85 \pm 0.81^{\mathrm{a}}$ & $101.25 \pm 9.99^{\mathrm{a}}$ \\
P-value & 0.938 & 0.075 \\
\hline
\end{tabular}

\subsection{Fruit and Seed Yield}

Analysis of variance and Tukey's test showed that the frequency of watering had a significant influence $(\mathrm{p}=0.00)$ on fruit and seed yields (Figure 13(a) \& Figure 13(b)). Watering every day produced more yield (30 fruits/plant; 15 seeds/Fruit; $2.4 \mathrm{~kg}$ of fruit and $700 \mathrm{~g}$ of seeds) than watering every Two days (18 fruits/plant; 9 seeds/fruit; $1.4 \mathrm{~kg}$ of fruit and $350 \mathrm{~g}$ of seeds). According to the results obtained, the pretreatments significantly influenced the yields parameters such the number of fruits per plant $(\mathrm{p}=0.020)$, the weight of fruits $(\mathrm{p}=0.003)$ and the weight of seeds ( $p=0.019)$. On the other hand, the pretreatments had no significant effect on the number of seeds per fruit $(\mathrm{p}=0.238)$. The higher yields in Lots 1 and 2 than Lots 3 and 4 were recorded (Table 3 ).

\section{Discussion}

\subsection{Germination}

Germination was an important prerequisite for continued growth and other physiological processes, including productivity and fruit and seed yield. According to our results, the germination of the seeds was not influenced by the light factor (Figure 7) during the entire experiment. According to Johnson et al. [14] who worked in greenhouses, the presence of light could sometimes shorten germination time while reducing cumulative germination rates by $10 \%$ to $20 \%$. What contradicts our results or the presence of light has no influence on the germination rate. In addition, the action of heat seems to be detrimental to the germination of the seeds, probably because of their high oil content [15]. However, the germination rate is strongly influenced by the different pretreatments. Indeed, the germination speed of seeds without pretreatment (Lot1) and those soaked in tap water (Lot2) is the fastest with a short lag time. Germination is started from the 4th and 5th day, it is rapid during the first days. On the other hand for the last two batches, we observe a longer latency time. So the pretreatments coated a slowdown in the speed of seed germination leading to a decrease in the germination rate. This result is in line with that obtained by Johnson et al. [14] who found that the improvement in germination was due to the weakening of the seed coats and thus making them permeable. Indeed, Benadjaoud and Aïd

[16] reported that soaking in hot water at more than $70^{\circ} \mathrm{C}$ did not allow any 

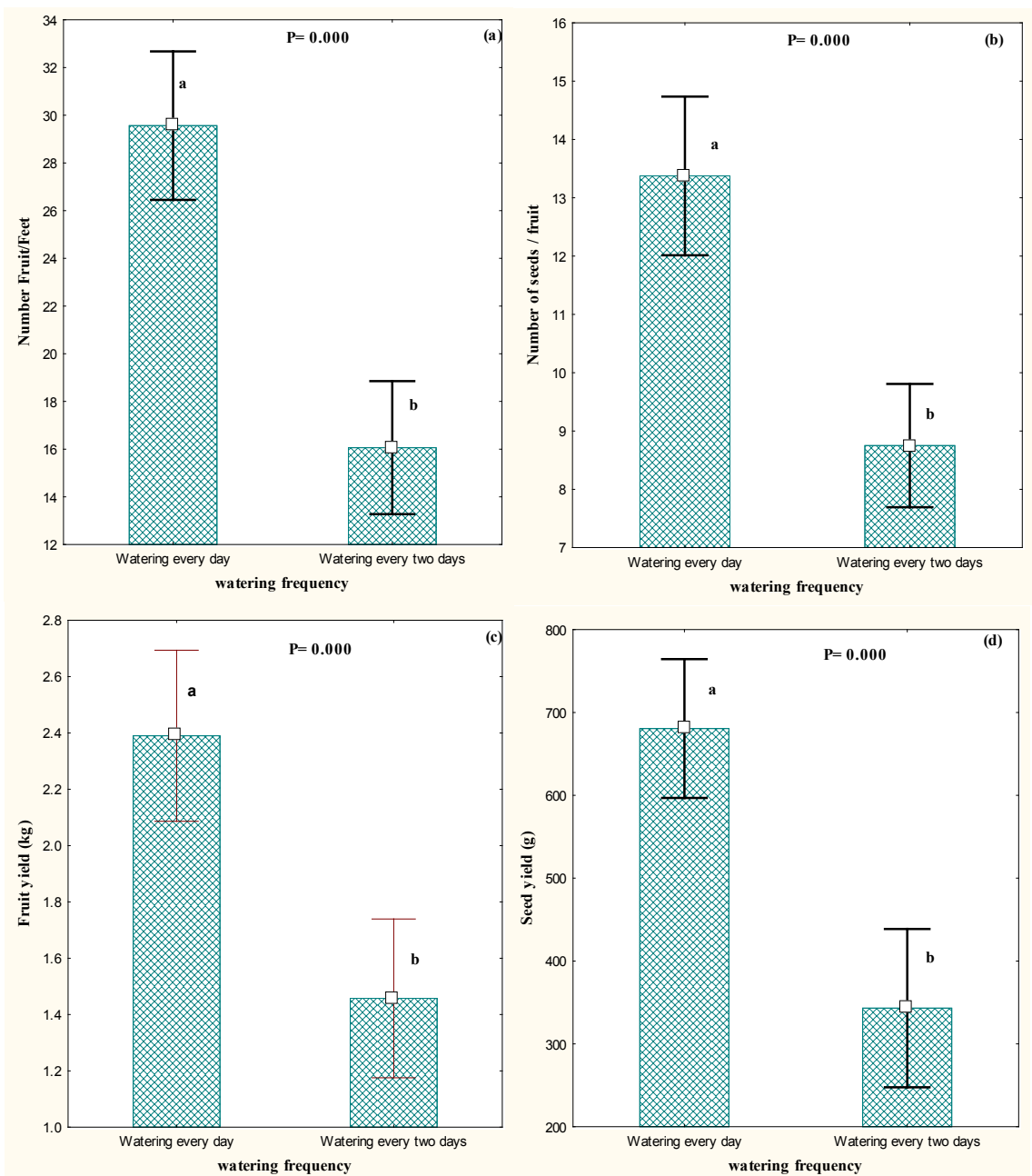

Figure 13. Yields: (a) number of fruit per plant; (b) number of seeds per fruit; (c) total mass of fruit and $(\mathrm{d})$ seeds.

Table 3. Yield in number of fruit and seeds depending on the pretreatments and the frequency of watering.

\begin{tabular}{ccccc}
\hline Pretreatments & NF/P & NS/F & Y.F (kg) & Y.S (g) \\
\hline Lot: 1 & $24.75 \pm 6.68^{\mathrm{ab}}$ & $12.25 \pm 3.15^{\mathrm{a}}$ & $2.4 \pm 0.69^{\mathrm{a}}$ & $609.92 \pm 200.37^{\mathrm{a}}$ \\
Lot: 2 & $28.62 \pm 7.92^{\mathrm{a}}$ & $12.25 \pm 3.45^{\mathrm{a}}$ & $2.29 \pm 0.52^{\mathrm{a}}$ & $628.88 \pm 191.90^{\mathrm{a}}$ \\
Lot: 3 & $22 \pm 7.91^{\mathrm{ab}}$ & $9.87 \pm 3.04^{\mathrm{a}}$ & $1.62 \pm 0.49^{\mathrm{ab}}$ & $499.67 \pm 218.6^{\mathrm{ab}}$ \\
Lot: 4 & $15.87 \pm 8.30^{\mathrm{b}}$ & $9.87 \pm 3.04^{\mathrm{a}}$ & $1.37 \pm 0.63^{\mathrm{b}}$ & $309.11 \pm 231.09^{\mathrm{b}}$ \\
P-value & 0.02 & 0.238 & 0.03 & 0.019
\end{tabular}

NF/P: Number of fruits per plant; NS/F: Number of Seeds per fruit (kg); Y.F: Fruit yield; YS: Seed yield (g).

germination after 4 weeks of tests on argan seeds. According to the authors, it is likely that this type of treatment has a depressive, even lethal, effect on the seeds. Based on the results, immersing the seeds for 24 hours in tap water results in a high germination rate. This pretreatment allowed the softening of the seed coats by promoting germination. Indeed, the pre-soaking induces in the seed a drop in 
the water potential of the embryo which leads to the synthesis of new substances of low molecular weight and this leads to a production of the energy cited by [17]. Another hypothesis which could explain this difference in the germination rate would be an intense hormonal activity in the seed coats which would temporarily inhibit this germination. However, this inhibition would be lifted by soaking the seeds in lukewarm water for 24 hours. Our results are in agreement with those found by Pamo et al. [18] on seeds soaked in lukewarm water between 12 and 72 hours provide the best germination rate (90\%). These germination rates are in phase with those obtained by Bembe et al. [4] on three cucurbits (Lagenaria siceraria, Citrullus lanatus and Cucurbita moschata) with respectively $78.57 \%$; 90.42\%; 92.85\%. Staying the seeds in tap water for 1 day did not have too much of an effect on the germination rate but reduced the germination time and delay by 3 days compared to the control. These results are in agreement with those reported by Ado et al. [5] on the seeds of Diospyros Mespiliformis. Furthermore, it should be noted that the duration of soaking the seeds in boiling water depends on the thickness and hardness of the seed coat [19]. The experiment carried out with the four (4) treatments showed that the seeds not pretreated and those treated with tap water gave a better percentage of germination than those treated with hot and boiling water. These results support the hypothesis of that each cultivar in cultivation requires a critical soaking time and it should be less than the safe limit [20]. According to these authors, having a thick seed coat does not allow good water absorption in the case of bitter gourd. This therefore results in late germination and also seed dormancy. Soaking seeds before sowing may be beneficial in this regard, but soaking time and heating are not very favorable for germination [20]. Soaking helps absorb water easily and also removes some pathogens from the surface of the seeds. Seed priming, the controlled hydration and dehydration of seeds, is widely used to increase the rate and uniformity of establishment of seedlings of commercial vegetable and flower seeds [21]. In addition, Kanwar et al. [22] reported that soaking may increase the activity of glyoxisome enzymes in bitter gourd seeds. In other words, germination and growth depend not only on the types of seeds, but also strongly influenced by many internal and external factors. For example, Harris et al. [20] reported that in winter germination of bitter gourd becomes late due to the soil temperature being lower than the required temperature. So at the moment the hot water treatment of the seeds allows better and earlier germination even in winter. A variety of cultivated species have shown faster germination, early emergence and vigorous sowing by soaking the seeds in hot water for the same time and then drying on the surface before sowing, which can result in a higher yield high cultures [20] [23]. The mean germination time is strongly influenced by the different pretreatments used. The best germination time ( 5 days) is obtained from seeds which have been soaked in tap water for 24 hours. Seeds treated with hot and boiling water also showed a short mean germination time (6 to 14 days). These results are consistent with those found by Achigan-Dako et 
al. [24] on three species of Egusi used in food in Benin. According to these authors, the germination time of these three species varies between 5 and 10 days. This same time interval was obtained by Zoro Bi et al. [2] on Phaseolus lunatus in Côte d'Ivoire.

\subsection{Influence of the Frequency of Watering on the Growth Parameters}

The growth dynamics of seedlings in the nursery revealed important information. Like the germination percentage, the growth (height and number of leaves) of plants was influenced by the quality of the seeds and the frequency of watering. However, the pretreatment factor has no influence on plant growth. After 3 months of the test, the average height of the plants is between $2.4 \mathrm{~m}$ and $1.5 \mathrm{~m}$ respectively for watering every day and every two (2) days (Figure 10). There is therefore a clear correlation between growth in plant size and germination rates. So plants watered every day grow faster than those watered every other day. We can assume that growth hormones would be present in large quantities in these seedlings watered every day. Therefore, the growth rate of $M$. charantia is better for the plants grown from the seeds of Lot2 (tap water). In a study conducted by Braconnier et Bourou [17] in India on six varieties of millet (Eleusine coracana L.) shows that plants grown from seeds pre-soaked with lukewarm water reduced the time to enter by $50 \%$ in bloom. Moreover, the study of juvenile growth of $M$. charantia has shown that this species grows rhythmically. It is a mode of growth whereby a stem or root meristem manifests cycles of morphogenetic activity passing through maximums and minimums or complete stops, at more or less equal time intervals [25]. This type of growth has also been demonstrated on plantlets of Terminalia avicennioides and Piliostigma thonningii [26]. The rhythmic growth of the aerial stem of seedlings is a consequence of the rhythmic functioning of the apical meristem. The waves of growth are linked to the bud burst, which manifests itself in the opening of the leaves and the successive formation of internodes [26]. Momordica charantia recorded the best height growth $(4.5 \mathrm{~m})$ in 60 days in the nursery. There is thus a variation in height growth and number of leaves with the type of watering. This variation could be explained not only by the physiological and genetic state of the seeds used, but also by the quality of the substrates used and the silvicultural care, in particular the watering given to the plants [27]. The leaves and the blade are important parameters in measuring growth and yield. This is because the seed when produced with healthier, well-watered seedlings, the plant will produce the best quality leaf, in length, width, color, size and shape. This may be due to earlier germination and less susceptible to pathogen attack as the treated seeds were washed in lukewarm water [28]. Moreover, the good aptitude for foliar production of Momordica charantia from an early age would constitute a factor which determines its important medicinal use by the population [9]. In addition, watering stimulates and produces enzymes like amylase and lipase which activate 
storage materials in the seeds and mobilize anti-oxidant enzymes which subordinate to oxidation in the seeds which keep the seeds vigorous. Causing earlier emergence of limbo. Rehydration causes early emergence by influencing the prégerminatifs germination processes [29]. Ultimately, the watering frequency factor promotes crop growth, the number of branches/plant and plant yield [23]. According to the results obtained, the average time required for the appearance of the first flowers is 1 month 28 days. It emerges from this study that the speed of flowering of the feet is fast and variable among the plants. The flowering period for the 15 followed plants is the month of September and the average length of fruit maturity turns around 14 to 15 days. Furthermore, the results revealed a faster flowering speed for $8,9,10,11$ and 12 plants with a fixed maturity time of 15 days. These five (5) feet were under the shade of the trees. According to this experience, the ideal fruit harvest period would be October, three (3) and a half months after sowing. Experience has shown that it takes two months to produce flowering plants of $M$. charantia. However, variations in the number of days before the first flowering were found to be very important for different pretreatments. The days required for the first flowering were recorded with frequent observations. However, the study also revealed that such a height of the plants is acquired on condition of using bags (plastic bags) as container and a substrate of clay-silty structure. Indeed, the good growth of $M$. charantia seedlings was observed on a compost made up of two thirds (2/3) of clayey soil mixed with one third $(1 / 3)$ of silty soil taken under cover of trees in the forest. . From the phenological data, it appears that the average time of appearance of flower buds of M. charantia is 38 days after sowing. These results are in line with those obtained by Bembe et al. [4] on Citrullus lanatus 31 days after sowing and 37 days after sowing in Lagenaria siceraria and Cucurbita moschata. Thus, the duration of the production cycle of the species studied is approximately 120 days, which is identical to that observed by Zoro Bi et al. [2]. According to the author, like all other families of cultivated leafy and vegetable plants, Cucurbitaceae have more or less similar vegetative characteristics. It emerges from this study that the average maturity of the fruits is two weeks and the ideal harvest period is between October and September. These results are consistent with those obtained by Balde et al. [9] during the ethnobotanical investigation of $M$. charantia in Senegal. According to these authors, the maximum period of maturity of the fruit is between 15 and 20 days (85.00\%) and the best time to harvest the fruit is the end of October and the beginning of November (91.50 In addition, Achigan-Dako et al. [24] observed in Cucumeropsis edulis a longer flowering time of 57 days. According to these authors, this species has the longest production cycle of all cucurbits ahead of the genus Momordica.

\subsection{Influence of the Frequency of Watering on the Fruit and Seed Yield}

From the results obtained, the average yield of fruits and seeds is strongly influ- 
enced by the pretreatments and the frequency factor of watering. Thus, the best yield of fruit and seeds is obtained by pretreatment with tap water (lot2) and the control (lot1). It appears from this study that watering every day gives a better yield of fruits and seeds. Consequently, $M$. charantia produces more fruit per plant than that of Cucumeropsi sedulis which produces an average of 5 fruits per plant [24]. Our results are superior to those obtained by Bembe et al. [4] on Lagenaria siceraria $332.80 \mathrm{~g}$; Cucurbita moschata $272.40 \mathrm{~g}$ and Citrullus lanatus $159.20 \mathrm{~g}$. The relationship between seed yield and number of fruits per plant can be a linear regression. Analysis of the latter can be considered as the best estimator of seed production for this plant. However, compensation in total seed yield is possible when the number of fruits per plant increases. Under growing conditions in West Africa, the performance that interests both the producer and the end consumer is the seed yield for the cucurbits used as Egusi and the genus Momordica [2] [24]. Thus, in this region of the world, cultivation programs for M. charantia will have to focus instead on increasing the seed yield for its oil.

\section{Conclusion}

Momordica charantia seeds had a good germination rate influenced by pretreatments and frequency of watering. Thus, soaking with tap water and watering every day stimulated a better germination. In addition, daily watering allowed a good growth in height and number of leaves. However, these growth parameters are not influenced by pre-treatments. For the fruit and seed productivity, soaking in tap water and daily watering produced higher yield. Finally, this study on the agronomic evaluation of $M$. charantia highlighted the germination rate, growth performance and productivity for a better domestication of the species.

\section{Acknowledgements}

We are grateful to the director and all the laboratory staff of PRONASEF (national forest seeds program) for their contribution to the success of this agronomic trial. Finally we would like to thank the Laboratoire d'Analyzes and Essais. Ecole Supérieure Polytechnique Université Cheikh Anta Diop. For continuing education in the agro-food industry for their support, contribution to scientific exploitation and data processing.

\section{Contributions des Auteurs}

Conceptualisation, Samba Balde, Nicolas Cyrille Ayessou, Antoine Sambou; Methodology and Visualisation, Samba Balde, Khadim Niane, Nicolas Cyrille Ayessou; Rédaction-brouillon original, Samba Balde, Khadim Niane; Révision, Papa Guedel Faye, édition et Software, Nicolas Cyrille Ayessou et Antoine Sambou; Supervision, Nicolas Cyrille Ayessou, Antoine Sambou, Mady Cisse, Codou Mar Diop. 


\section{Conflicts of Interest}

The authors declare no conflicts of interest regarding the publication of this paper.

\section{References}

[1] Williams, J.T. (2002) Global Research on Underutilized Crops: An Assessment of Current Activities and Proposals for Enhanced Cooperation. Bioversity International, Rome.

[2] Zoro Bi, I., Maquet, A. and Baudoin, J.-P. (2003) Population Genetic Structure of wild Phaseolus lunatus (Fabaceae), with Special Reference to Population Sizes. American Journal of Botany, 90, 897-904.

[3] Zoro Bi, I., Koffi, K.K., Dje, Y., Malice, M. and Baudoin, J.-P. (2006) Indigenous Cucurbits of Côte d'Ivoire: A Review of Their Genetic Resources. The Science of Nature, 3, 1-9.

[4] Bembe, A., Mabanza, J., Mingui, J. and Mialoundama, F. (2016) Etude de Quelques Caractères Végétatifs chez Trois Espèces de Cucurbitacées Locales Cultivées au Congo Brazzaville: Lagenaria Siceraria, Citrullus Lanatus et Cucurbita Moschata. Annale des Sciences et Techniques, 11, 4.

[5] Ado, A., Bil-Assanou, I.H., Iro, D.G., Karim, T.D.A., Ali, M. and Mahamane, S. (2017) Effet De Prétraitements, De Substrats Et De Stress Hydriques Sur La Germination Et La Croissance Initiale De Diospyros Mespiliformis Hochst. Ex A.DC. European Scientific Journal, 13, 231. https://doi.org/10.19044/esj.2017.v13n21p231

[6] Fernandes, N.P., Lagishetty, C.V., Panda, V.S. and Naik, S.R. (2007) An Experimental Evaluation of the Antidiabetic and Antilipidemic Properties of a Standardized Momordica charantia Fruit Extract. BMC Complementary and Alternative Medicine, 7, Article No. 29. https://doi.org/10.1186/1472-6882-7-29

[7] Mahajan, T.S. and Pandey, O.P. (2015) Effect of Electric and Magnetic Treatments on Germination of Bitter Gourd (Momordica charantia) Seed. International Journal of Agriculture and Biology, 17, 351-356.

[8] Ashrafuzzaman, M., Ismail, M.R., Fazal, K., Uddin, M.K. and Prodhan, A. (2010) Effect of GABA Application on the Growth and Yield of Bitter Gourd (Momordica charantia). International Journal of Agriculture and Biology, 12, 129-132.

[9] Balde, S., Ayessou, N.C., Gueye, M., Ndiaye, B., Sow, A., Cisse, O.I.K., et al. (2019) Investigations Ethnobotaniques de Momordica charantia Linn (Cucurbitaceae) au Sénégal. International Journal of Biological and Chemical Sciences, 13, 466-474. https://doi.org/10.4314/ijbcs.v13i1.37

[10] Florez, M., Carbonell, M.V. and Martínez, E. (2007) Exposure of Maize Seeds to Stationary Magnetic Fields: Effects on Germination and Early Growth. Environmental and Experimental Botany, 59, 68-75.

https://doi.org/10.1016/j.envexpbot.2005.10.006

[11] Marks, N. and Szecówka, P.S. (2010) Impact of Variable Magnetic Field Stimulation on Growth of Aboveground Parts of Potato Plants. International Agrophysics, 24, $165-170$.

[12] Soumana, D., Moustapha, A.M., Kolafane, A., Issa, A. and Nouhou, B.A. (2019) Effet du Régime d'Irrigation sur la Germination et la Croissance en Pépinière de Parkia Biglobosa (Jacq.) G. Don. Journal of Animal and Plant Sciences, 40, 6573-6583. 
[13] Zerbo, P., Belem, B., Mllogo-Rasolodimby, J. and Van Damme, P. (2010) Germination Sexuée et Croissance Précoce d'Ozoroa Insignis Del., Une Espèce Médicinale du Burkina Faso. Cameroon Journal of Experimental Biology, 6, 74-80. https://doi.org/10.4314/cajeb.v6i2.68524

[14] Johnson, B.N., Quashie, M.A., Radji, R., Segla, K.N., Adjonou, K., Kokutse, A.D., et al. (2019) Etude de la Germination de Lawsonia inermis L. Sous Différentes Contraintes Abiotiques. International Journal of Biological and Chemical Sciences, 13, 745-758. https://doi.org/10.4314/ijbcs.v13i2.14

[15] Guimbo, I.D., Ambouta, K.J.M., Mahamane, A. and Larwanou, M. (2011) Germination et Croissance Initiale de Neocarya Macrophylla (Sabine) Prance, une Espèce Oléagineuse du Niger. Tropicultura, 29, 88-93.

[16] Benadjaoud, A. and AÏD, F. (2004) Effets de Quelques Traitements PhysicoChimiques et de la Temperature sur la Faculte Germinative des Graines de Parkinsonia aculeata L. Annales de P Institut National Agronomique El Harrach, 25, 19-30.

[17] Braconnier, S. and Bourou, S. (2004) Etude du Pré-Trempage des Graines de Niébé dans l'Eau Comme Solution Technique Simple Pour Améliorer la Tolérance à la Sécheresse du Niébé. Centre d Etudes Régional Pour 1 Amélioration de I Adaptation à la Sécheresse, Sénégal.

[18] Pamo, E.T., Tendonkeng, F., Kana, J.R., Loyem, P.K., Tchapga, E. and Fotie, F.K. (2004) Effet de Différents Niveaux de Supplémentation avec Leucaena leucocephala sur la Croissance Pondérale de la Chèvre Naine de Guinée. Revue délevage et de Médecine Vétérinaire des Pays Tropicaux, 57, 107-112. https://doi.org/10.19182/remvt.9898

[19] Dardour, M., Daroui, E.A., Boukroute, A., Kouddane, N.E. and Berrichi, A. (2014) Etude de Prétraitements des Graines de Brachychiton populneus (Schott \& Endl.) R. Br. et B. Acerifolius F. Muell. en Faveur de leur Germination (Study of Pretreatment Seeds Brachychiton populneus (Schott \& Endl.) R. Br. and B. acerifolius F. Muell. for Germination). Journal of Materials and Environmental Science, 5, 1877-1884.

[20] Harris, D., Tripathi, R.S. and Joshi, A. (2002) On-Farm Seed Priming to Improve Crop Establishment and Yield in Dry Direct-Seeded Rice. In: Pandey, S., Mortimer, M., Wade, L., Tuong, T.P., Lopes, K. and Hardy, B., Eds., Direct Seeding. Research Strategies and Opportunities, International Research Institute, Manila, 231-240.

[21] Asamoah, F.O. (2016) Effect of Different Priming Concentrations on Germination and Seedling Performance of Age-Accelerated Seeds of Three Okra (Abelmoschus Esculentus L) Varieties. PhD Thesis, Kwame Nkrumah University of Science and Technology, Kumasi.

[22] Kanwar, R., Mehta, D.K. and Lal, M. (2014) Effect of Seed Priming on Physiological Parameters of Aged and Non-Aged Seeds of Bitter Gourd, Momordica charantia L. International Journal of Farm Sciences, 4, 24-32.

[23] Upadhyay, A., Agrahari, P. and Singh, D.K. (2015) A Review on Salient Pharmacological Features of Momordica charantia. International Journal of Pharmacology, 11, 405-413. https://dx.doi.org/10.3923/ijp.2015.405.413

[24] Achigan-Dako, A.G. and Baudoin, J.-P. (2007) Cucumis melo L. subsp. Agrestis (Naudin) Pangalo (Cucurbitaceae): Nécessité d'une Clarification sur le Statut de la Sous-Espèce. Biotechnologie, Agronomie, Société et Environnement, 11, 283-286.

[25] Collin, P., Badot, P.M., Millet, B. and Barnola, P. (1995) Etude de la Croissance et du Développement chez le Frêne Commun, Fraxinus Excelsior, Cultivé en Conditions Contrôlées. Canadian Journal of Botany, 73, 1464-1470. 
https://doi.org/10.1139/b95-159

[26] Bationo, B.A., Some, N.A., Ouedraogo, S.J. and Kalinganire, A. (2010) Croissance Comparée des Plantules de Cinq Espèces Ligneuses Soudaniennes Elevées en Rhizotron. Science et Changements Planétaires/Sécheresse, 21, 196-202.

https://www.jle.com/10.1684/sec.2010.0255

[27] Amani, A., Inoussa, M.M., Guimbo, I.D., Mahamane, A., Saadou, M. and Lykke, A.M. (2015) Germination et Croissance de Quatre Espèces de Combretaceae en Pépinière. Tropicultura, 33, 135-145.

[28] Ashraf, M. and Foolad, M.R. (2005) Pre-Sowing Seed Treatment-A Shotgun Approach to Improve Germination, Plant Growth, and Crop Yield under Saline and Non-Saline Conditions. Advances in Agronomy, 88, 223-271.

https://doi.org/10.1016/S0065-2113(05)88006-X

[29] Farooq, M., Basra, S.M.A., Hafeez, K., Asad, S.A. and Ahmad, N. (2005) Use of Commercial Fertilizers as Osmotica for Rice Priming. Journal of Agriculture \& Social Sciences, 1, 172-175. 